\title{
PENGEMBANGAN PERANGKAT PEMBELAJARAN IPA MODEL LEARNING CYCLE 5E UNTUK MELATIHKAN KEMAMPUAN BERPIKIR KREATIF SISWA SMP NEGERI 2 KEMBANG TANJONG
}

\author{
Zuraida $^{1}$, Zufahmi ${ }^{2}$ \\ e-mail:raidazuraida4@gmail.com \\ ${ }^{1,2}$ Program Studi Pendidikan Biologi Universitas Jabal Ghafur
}

\begin{abstract}
ABSTRAK
Tuntutan generasi yang mampu bersaing secara global adalah generasi yang dibekali dengan kemampuan berpikir kreatif dan memiliki karakter yang kuat. Berpikir kreatif merupakan bagian dari kemampuan berpikir tingkat tinggi dan menjadi komponen penting dalam menghadapi isu tuntutan abad ke-21. Kondisi tersebut dirasa perlu dilibatkan siswa dilatihkan kemampuan berpikir kreatif supaya mereka siap menghadapi tantangan yang sulit di masa mendatang. Kemampuan berpikir kreatif bersifat divergen dari siswa mencakup aspek fluency (kelancaran menggukapkan ide), flexibility (kemampuan mengungkapkan ide yang berbeda), originality (keaslian, keunikan ide), dan elaboration (pemberian rinci dan penjelasan pada ide yang dibuat). Tujuan penelitian ini untuk mengembangkan perangkat pembelajaran IPA dengan menggunakan model Learning cycle 5E yang layak untuk melatih siswa berkemampuan berpikir kreatif di SMP Negeri 2 Kembang Tanjong. Penelitian ini dilakukan pada tahun 2019 di SMP Negeri 2 Kembang Tanjong di kabuapten Pidie dengan model Perangkat pembelajaran Learning cycle 5E untuk melatih berpikir kreatif siswa.Luaran wajib adalah Jurnal nasional tidak terakreditasi dengan pengembangan perangkat pembelajaran dengan model Learning cycle 5E khususnya pada pembelajaran IPA di SMP. Luaran tambahan jurnal ilmiah terakreditasber ISSN pada tingkat nasional. Pengembangan perangkat menggunakan model pengembangan 4D dengan rancangan One-Group Pre test-Post test Design. Perangkat yang dikembangkan yakni perangkat pembelajaran IPA pada materi pencemaran lingkungan terdiri dari (silabus, Rencana Pelaksanaan Pembelajaran (RPP), Lembar Kerja Siswa (LKS), Buku ajar Siswa (BAS), dan tes kemampuan berpikir kreatif. Sasaran penelitian adalah perangkat pembelajaran yang diuji cobakan pada 35 siswa SMP kelas VIIB dengan menggunakan perangkat pembelajaran model Learning cycle 5E. Pengumpulan data menggunakan metode obeservasi, tes dan angket. Teknik analisis data dilakukan secara deskriptif kualitatif dan kuantitatif. Tingkat Kesiapan Teknologi (TKT) dalam penelitian ini adalah tingkat pada tahun pertama adalah 5 dan tahun berikut adalah 6 . Perangkat yang dikembangkan valid dengan kategori sangat baik. Terlaksanaan pembelajaran berjalan dengan baik karena keterlibatan siswa dalam belajar lebih aktif. Kemampuan berpikir kreatif menunjukkan Skor N-Gain berkategori tinggi. Adanya peningkatan kemampuan secara signifikan berpikir kreatif, hal terlihat pada pre-test dan post-test dari indikator yang diukur pada aspek kelancaran (fluency) dan fleksibilitas (flexibility). Indikator elaborasi (elaboration) dan keaslian (originality) merupakan indikator yang memiliki peningkatan rendah dari pre test dan pos test, karena masih banyak siswa yang belum mampu menggaitkan materi yang mereka miliki untuk memperjelas ide dan siswa terpaku oleh beberapa hal yang dijelaskan di buku dalam mengatasi pencemaran lingkungan.Proses pembelajaran mendapat respon positif dari siswa dan kendala proses pembelajaran telah diberikan alternatif solusi. Berdasarkan hasil penelitian dapat disimpulkan bahwa pengembangan perangkat pembelajaran IPA model Learning cycle 5Elayak dan dapat melatihkan kemampuan berpikir kreatif siswa SMP Negeri 2 Kembang Tanjong.
\end{abstract}

Kata Kunci: Perangkat pembelajaran, Model Learning Cycle 5E, Berpikir kreatif, Pencemaran Lingkungan

PENDAHULUAN

Salah satu sasaran dari tujuan kurikulum 2013 adalah mempersiapkan manusia Indonesia memiliki kemampuan berpikir kreatif. Tuntutan generasi yang mampu bersaing secara global adalah 
generasi yang dibekali dengan kemampuan berpikir kreatif dan memiliki karakter yang kuat. Berpikir kreatif merupakan bagian dari ranah kemampuan berpikir tingkat tinggi sehingga dianggap penting dalam menghadapi isu tuntutan abad ke-21. Hal tersebut sependapat dengan yang dikemukan oleh Piitro (2011) menyatakan bahwa "Salah satu fokus pendidikan berbagai negara di dunia saat ini adalah pada keterampilan abad 21 adalah berpikir kreatif.

Sasaran tujuan yang dipaparkan di atas belum mencapai hasil maksimal, hal ini adanya termuan yang dilakukan oleh survey international salah satunya yang diselenggarakan oleh "Programme for International Student Assesment (PISA)"tahun 2012 melaporkan bahwa Indonesia menempati peringkat 64 dari 65 negara peserta PISA, khususnya mata pelajaran IPA (Sains) dengan peroleh skornya 382, sedangkan seluruh peserta memperoleh skor rata-rata mencapai 500 (Thomsom, 2014). Rendahnya hasil yang didapatkan pada uji Internasional mungkin disebabkan oleh siswa-siswi yang ada di Indonesia sudah terbiasa mengerjakan soalsoal yang hanya menekan pada pengusaan konsep hasil belajar saja, namun kemampuan berpikir kreatif belum mendapat perhatian khusus.

Berdasarkan observasi yang dilakukan di SMP Negeri 2 Kembang Tanjong, ditemukan informasi bahwa selama ini guru IPA belum menyusun perangkat pembelajaran yang mengacu siswa berpikir kreatif. Kegiatan pembelajaran yang mengarah berpikir kreatif belum berjalan maksimal.Penyebautamanya keterbatasan waktu guru dalam mengembangkan perangkat pembelajaran berpikir kreatif. Proses pembelajaran yang dilakukan masih didominasi guru dan belum mengacu pada pendekatan kontruktivis, sehingga siswa kurang terlibat aktif dalam proses pembelajaran. Tujuan pendekatan konstruktivis yakni, memberikan pengalaman kepada siswa untuk mengkonfirmasi konsepsi yang sebelumnya sudah dimilikinya (Aydin dan Yilmaz, 2010).

Keberhasilan siswa dalam belajar hanya dipandang oleh guru ditentukan oleh hasil belajar aspek pengetahuan (kognitif) saja namun aspek berpikir kreatif cenderung diabaikan, untuk itu dirasa perlu dicari solusi yang tepat dalam mengembangkan perangkat pembelajaran sesuai dengan harapan kurikulum 2013.

Salah satu model yang dipandang sejalan dengan prinsip pendekatan ilmiah serta dapat meningkatkan kemampuan berpikir kreatif siswa adalah model Learning cycle 5E. Model Learning cycle 5E sebagai solusi alternatif perlu dikembangkan untuk mencapai kompetensi dasar materi pecemaran lingkungan dan melatihkan kemampuan berpikir kreatifsiswa. Menurut Bybee (2009). tahapan aktivitas dalam Learning cycle $5 E$ berpotensi mendorong siswa berpikir kreatif komponen penting keterampilan abab 21.

Berdasarkan uraian di atas, maka akan dilakukan penelitian dengan judul "Pengembangan Perangkat Pembelajaran IPA Model Learning Cycle 5E untuk Melatihkan Kemampuan Berpikir Kreatif Siswa SMP Negeri 2 Kembang Tanjong"Secara umum rumusan masalah dalam penelititan ini adalah: "Bagaimana kelayakan perangkat pembelajaran IPA model Learning cycle $5 E$ melatihkan kemampuan berpikir kreatif siswa SMP Negeri 2 Kembang Tanjong?".Adapun tujuan dalam penelitian ini adalah mengembangkan perangkat pembelajaran IPA model Learning cycle 5Eyang layak untuk melatih kemampuan berpikir kreatif siswa SMPNegeri 2 Kembang Tanjong. Urgensi dalam penelitian yang diharapkan antara lain: 1) Tersedianya perangkat pembelajaran yang dapat melatihkan kemampuan berpikir kreatif pada pembelajaran IPA siswa SMP Negeri 2 Kembang Tanjong dengan menggunakan model Learning cycle 5E dan 2) Siswa perlu dilatih kemampuan berpikir kreatif sebagai respon tantangan masa datang dalam menyelesai masalah di masyarakat 


\section{METODE PENELITIAN}

Jenis penelitian ini merupakan penelitian pengembangan (developmental research), dengan merujuk pada model pengembangan 4D yang dimofidikasi sampai pada tahap develop saja, karena hanya diimplementasi satu kelas ujicoba sebanyak 35 siswa. Ujicoba dilaksanakan di SMP Negeri 2 Kembang Tanjong pada semester genap Tahun pelajaran 2018/2019 dengan menggunakan perangkat pembelajaran model Learning cycle $5 E$ pada materi pencemaran lingkungan yang terdiri dari Silabus, RPP, LKS, dan Buku ajar Siswa, serta instrument penilaian yang telah divalidasi oleh tiga pakar. Desain penelitian menggunakan rancangan penelitian OneGroup Pretest-Postest Design yang dikembangkan oleh Campbell dan Stanley (Sugiyono, 2013). Teknik pengumpulan data dalam penelitian ini adalah dokumentasi, observasi, angket, dan tes. Teknik analisis data dilakukan secara deskriptif kualitatif dan kuantitatif. Tingkat Kesiapan Teknologi (TKT) dalam penelitian ini adalah tingkat pada tahun pertama adalah 5 dan tahun berikut adalah 6 . Instrumen yang digunakan yang telah susun mengaptasikan dari penelitian yang relevan sebelumnya dengan dikondisikan pada kebutuhan penelitian.

\section{HASIL DAN PEMBAHASAN}

Perangkat pembelajaran yang telah dikembangkan dengan menggunakan model Learning cycle $5 E$ kemudian divaliadasi oeh tiga pakar (validator) terdiri dari: Silabus, Rencana Pelaksanaan, Lembar Kegiatan Siswa (LKS), Buku ajar siswa, dan instrument penilaian (tes kemampuan berpikir kreatif), keterlaksanaan pembelajaran serta respon siswa dari kegiatan pembelajaran akan dipaparkan sebagai berikut.

\section{A. Validitas Perangkat Pembalajaran}

Hasil pengembangan perangkat pembelajaran IPA model Learning cycle 5E yang dikembangkan berkategori valid dan sangat valid serta realibel untuk digunakan dalam pembelajaran kelas $\mathrm{VII}_{\mathrm{B}}$ untuk melatihkan kemampuan berpikir kreatif. Hasil validitas berupa skor terhadap perangkat pembelajaran yang diberikan oleh validator berdasarkan hasil validasi antaranya Silabus yang dikembangkan memiliki dua kategori berupa valid dan sangat valid, serta reliable. Validitas RPP dari aspek yang dinilai juga memiliki kategori valid dan sangat valid dengan tingkat reliabilitas sebesar sebesar 96,89\%. LKS aspek dinilai terdiri dari aspek petunjuk, penjabaran rangkaian materi, serta alat bahan memiliki kategori valid, sedangkan prosedur berkategori sangat valid serta tingkat reliabilitasnya yaitu $96,41 \%$. Rata-rata reliabitas buku ajar sebesar 97,47\% dan kategori reliable yang dilihat aspek kelayakan, penyajian, bahasa serta keterbacaannya. Hasil tersebut menunjukkan RPP, LKS serta Buku aja siswa yang telah dikembangkan layak digunakan dalam proses pembelajaran.

Hasil validitas tes berpikir kreatif untuk aspek validasi isi kategori dan aspek bahasa masuk valid dan sangat valid, sehingga instrument tersebut layak untuk digunakan.

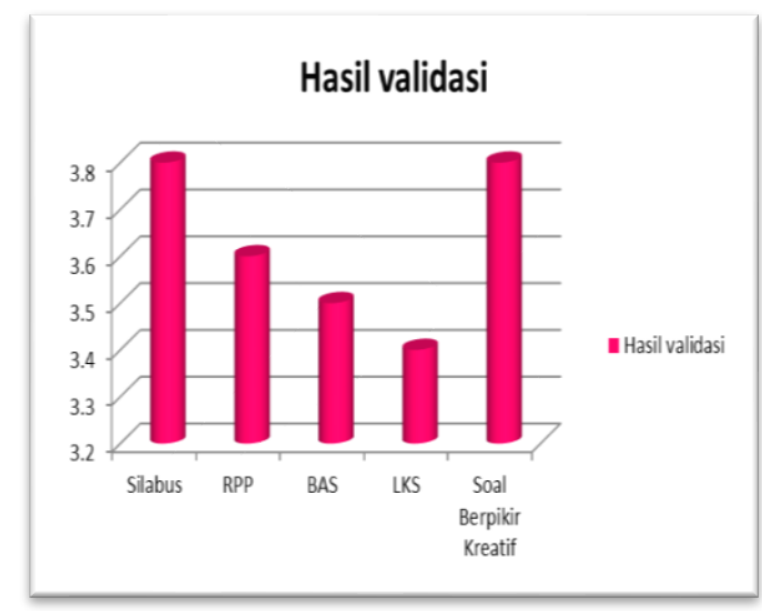

Gambar 1. Diagram Hasil validasi Perangkat Pembelajaran

\section{B. Kepraktisan Perangkat Pembelajaran}

Kepraktisan perangkat pembelajaran dalam penelitian ditinjau dari pengamatan keterlaksanaan pembelajarandan respon siswa. 


\section{Keterlaksanaan Pebelajaran}

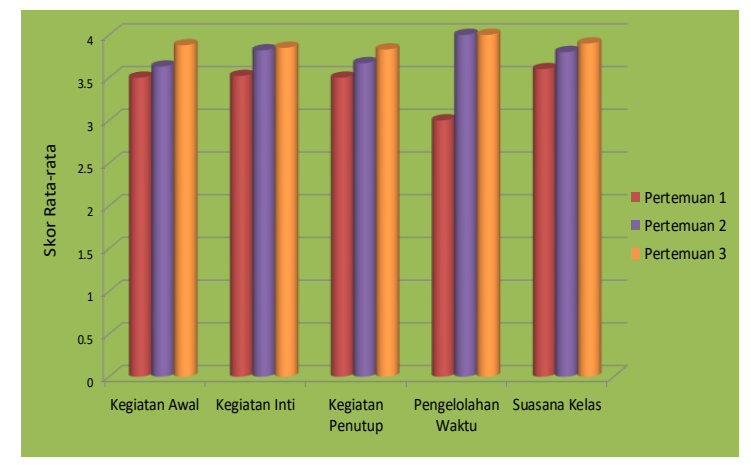

Gambar 2. Diagram Hasil Pengamatan Keterlaksanaan Pembelajaran

\section{Kepraktisan}

pengembangan perangkat pembelajaran dapat ditinjau dari hasil pengamatan keterlaksanaan RPP dan respon siswa terhadap proses pembelajaran. Berdasarkan hasil pengamatan yang telah dilakukan oleh dua pengamat seperti terlihat dari diagram gambar di atas menunjukkan bahwa RPP tahap awal merupakan kegiatan pendahuluan dari tiga pertemuan tersebut rata-rata berkategori sangat baik dengan skor sebesar 3,67. Kegiatan pembelajaran dari seluruhnya masuk tahap pendahuluan yaitu siswa berdoa pada awal pembelajaran, mengecek kehadiran, guru memotivasi siswa, serta menyampaikan tujuan pembelajaran dengan sangat baik (Akbar, 2013). Terlihat bahwa dari keempat fase engagement tersebut, guru berupaya mendapat perhatian dari siswa agar termotivasi dalam kegiatan pembelajaran. Motivasi siswa yang kuat memiliki dampak yang baik bagi pembelajaran, dan diharapkan agar siswa lebih antusias serta memiliki nilai ketertarikan terhadap proses kegiatan belajar mengajar (KBM). Kegiatan pembelajaran yang baik tahap ini juga memiliki indikasi meningkatkan keingintahuan (curiosity) siswa. Meningkatnya motivasi dan antusiasme siswa dalam proses pembelajaran juga berdampak meningkatnya kemampuan berpikir kreatif siswa (Munandar, 2009).

Tahap kedua adalah kegiatan intiterdiri dari fase exploration, explanation, elaboration, evaluation. Secara keseluruhan kegiatan int i dari pembelajaran masuk kategori sangat baik dengan skor rata-rata 3,73. Secara keseluruhan pada kegiatan inti pembelajaran masuk kategori sangat baik Proses pembelajaran dari kegiatan inti berjalan sesuai dengan rencana pembelajaran yang telah dikembangkan. Guru berupaya mendorong siswa mengeksplorasi pengetahuan secara aktif dalam proses pembelajaran dengan menggunakan setting kelompok. Hal ini sesuai yang diharapkan dengan model Learning cycle $5 E$ adanya keterlibatan siswa secara aktif sehingga tujuan pembelajran yang diharapkan tercapai karena mengacu pada pendekatan kontruktivis. Pendekatan kontruktivis mendorong siswa membangun pengetahuan sendiri dari apa yang yang dipelajarinya (Yatim, 2008). Selain itu setting kelompok membantu memicu terjadinya interaksi social dalam memberikan informasi tentang apa yang sedang dipelajari. Setting kelompok belajar membantu siswa dalam belajar mengarah proses scaffolding. Hal ini sejalan dengan pendapat Vigotsky (dalam Slavin, 2011), siswa dalam kelompok belajar saling berkerja sama dan memberikan bantuan terhadap anggotanya, jika mengalami kesulitan pada tahap-tahap awal pembelajaran, kemudian mengurangi bantuan tersebut sedikit demi sedikit dan kemudian diberikan kesempatan untuk mengambil ahli tanggung jawabnya setelah anggota mampu melakukannya. Pada tahap kegiatan inti, siswa juga terfasilitasi dengan pembelajaran untuk menyampaikan temuan (ide) serta bertukar pendapat dalam poster ilmiah dari masing-masing kelompok.

Tahap selanjutnya adalah penutup memiliki skor rata-rata 3,66 dengan kategori sangat baik (Akbar, 2013). Kondisi ini dikarenakan guru secara melibatkan siswa secara aktif untuk menyimpulkan materi pembelajaran yang mengacu pada tujuan pembelajaran dan siswa yang belum mengerti juga diberikan kesempatan untuk bertanya sebelum pembelajaran diakhiri. Selain itu kegiatan penutup guru memberi apreasiasi bagi siswa yang memiliki kinerja kelompok baik, dengan harapan siswa lebih termotivasi dalam belajar.Kegiatan penutup lain guru selalu mengingatkan siswa mempelajari kembali materi yang telah 
dipelajariSelanjutnya jika ditinjau secara rinci pada kegiatan pertemuan I, kegiatan menyimpulkan masih rendah jika dibandinga pertemuan II dan III yang mengalami peningkatan, hal ini terlihat dari skor rata-rata adalah 3,5. Hal ini disebabkan oleh faktor siswa belum terbiasa secara aktif dalam menyimpulkan pembelajaran.

Penggelolaan waktu memiliki rata-rata skor 3,66 dengan kategori baik. Pengelolaan waktu pada pertemuan pertama hanya memiliki rata-rata 3,00 karena siswa belum terbiasa dengan model Learning cycle $5 E$ saat proses pembelajaran, sehingga proses kegiatan pembelajaran memerlukan waktu lebih banyak daripada waktu yang ditetapkan peneliti. Temuan pada pertemuan I, terkait penggelolaan waktu segera diperbaiki oleh peneliti dengan cara mencari solusi yang tepat dan memanfaatkan waktu secara efektif dan efisien pada pertemuan berikutnya yaitu pertemuan II dan Pertemuan III sehingga skornya rata-rata sebesar 4 dengan kategori sangat baik. Keadaan pengelolaan kelas memiliki skor rata-rata 3,76 dengan kategori sangat baik. Hal ini memberikan indikasi bahwa adanya antusias antara guru dan siswa dalam pelaksanaan pembelajaran berjalan dengan baik. Proses pembelajaran dengan suasana kelas yang menyenangkan akan memberi kesempatan bagi untuk mengemukan pendapat dan ide baru serta menjadi lingkungan secara baik dalam mengembangkan kemampuan berpikir kreatif siswa.beberapa tindakan yang dilakukan guru untuk melatihkan berpikir kreatif siswa di kelas, dikarena mendorong siswa untuk berpikir secara divergen. Siswa didik untuk bersikap toleransi dengan perbedaan pendapat di kelompok dan diskusi di kelas, diberikan waktu, bahan serta ruang untuk melakukan proyek kreatif dengan membuat poster sebagai tugas di rumah. Ini sesuai dengan pernyataan (Fleith; 2000 dan Sattler; 1992) mengenai panduan untuk mendorong berpikir kreatif yang dilakukan oleh guru.

Dari paparan yang telah dijelaskan dapat disimpulkan hasil pengamatan keterlaksanaan RPP selama tiga kali pertermuan pada pelajaran IPA berjalan dengan sangat baik dengan skor rata-rata sebesar 3,7. Presentase keterlaksanaan RPP sebesar $100 \%$.Hal ini menunjukkan bahwa semua scenario yang direncanakan dapat terlaksanakan dengan sangat baik sesuai dengan RPP yang dikembangkan oleh peneliti dan perangkat masuk kategori reliable sehingga layak digunakan terhadap variable yang diukur meningkatkan berpikir kreatif.

\section{Respon Siswa}

Respon siswa merupakan tanggapan siswa terhadap komponen-komponen perangkat pembelajaran dan suasana pembelajaran IPA yang telah dikembangkan dengan menggunakan model Learning cycle $5 E$, diketahui memiliki persentase positif sebesar $83 \%$ tertarik terhadap suasana belajar, 97\% siswa memberikan respon bahwa cara guru mengajar dan membimbing secara jelas, serta siswa setuju menggunakan perangkat IPA dengan menggunakan model Learning cycle 5Esebesar 83\%. Hasil analisis data respon siswa ini, mengadptasikan skala Guttman dengan konversi intervalnya 80\%-100\% dengan kategori sangat kuat (Riduwan, 2010). Respon positif yang dari kegiatan proses pembelajaran juga diperkuat oleh temuan penelitian sebelumnya yaitu Prastiwi dan Anggaryani (2014), "Pelaksanaan pembelajaran Learning cycle $5 E$ memberikan respon positif terhadap pembelajaran yang telah dilakukan.

Minat berkaitan dengan motivasi, oleh karena itu motivasi merupakan salah unsur yang paling penting dalam proses pembelajaran. Motivasi merupakan suatu proses internal dalam diri seseorang untuk terus mempertahan perilaku tertentu (Nur, 2008). Perilaku yang ditujukan dari motivasi salah satu faktornya disebabkan siswa menyukai pelajaran yang disajikan oleh guru. Hal ini sesuai dengan hasil penelitian Wulandari, Nugroho, dan Putut(2013), menyatakan bahwa jika siswa menyukai pembelajaran, maka rasa ingin tahu siswa 
meningkat dan juga lebih termotivasi mengikuti pembelajaran.

Respon siswa terhadap instrument tes kemampuan berpikir kreatif jugamemiliki kategori respon positif, hal ini terlihat dari angket respon siswa sebesar $71 \%$. Siswa antusias dan aktif selama proses pembelajaran, karena guru mandorong siswa untuk berpikir divergen serta saling toleransi terhadap pendapat temannya ketika diskusi kelompok. Adanya pemberian Lembar Kegiatan siswa (LKS) dan Buku ajar siswa (BAS), juga memberikan dampak yang baik untuk berpikir kreatif siswa dikarena siswa merasa lebih mudah serta lancar pada saat mengerjakan soal kemapuan berpikir kreatif.

\section{Kefektifan Perangkat Pembelajaran}

Keefektifan perangkat pembelajaran yang telah dikembangkan ditinjau dari hasil peningkatan kemampuan pada indikator berpikir kreatif siswa saat pre test dan post test. Peningkatan hasil belajar juga berpengaruh terhadap efektififan perangkat dalam penelitian ini. Instrumen tes kemampuan berpikir kreatif yang digunakan dalam penelitian mengaptasikan dari skor Guilford Alternate Use. Skor dari GuilfordAlternate Useyang digunakan berhubungan dengan originality, fluency, flexibility, elaboration (Nur, 2014). Originality, fluency, flexibility, elaboration merupakan indikator yang sasaran karakteristik dari berpikir kreatif

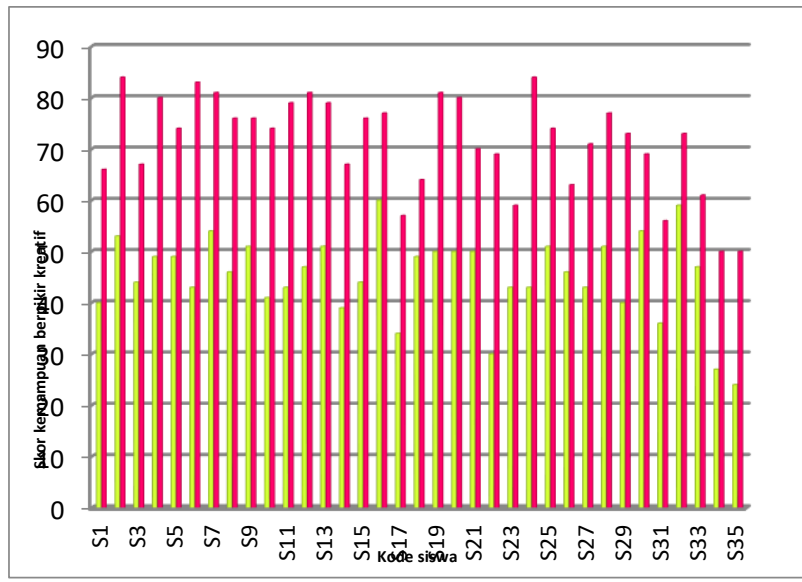

Gambar 3. Diagram tes kemampuan berpikir kreatif siswa

Kelancaran (fluency)dari hasilpre-test dan post-test. Kelancarkan berkaitan kemampuan mengciptakan ide sebanyaknya, dan menjadi salah satu indikator yang kuat untuk meninjau kemampuan berpikir kreatif. Semakin banyak ide yang diciptakan semakin besar mendapat ide secara signifikan.

Adanya peningkatan indikator skor kelancaran secara signifikan dari respon siswa, hal disebabkan oleh RPP dikembangkan menuangkan berbagai tindakan guru ketika kegiatan proses pembelajaran berlangsung dalam meningkatkan kemampuan berpikir kreatif siswa, dengan mendorong mereka untuk berpikir secara divergen dan memberikan kesempatan kepada siswa dalam sesi mengemukan pendapat, sehingga membantu mereka dalam menyelesaikan permasalahan dari kegiatan LKS. Siswa dapat terlibat secara aktif dalam mengungkapkan ide-ide mereka dikarena guru mengajak mereka untuk melakukan sesi mengemukan pendapat, hal ini sangat membantunya dalam menyelesaikan permasalahan. Hal ini sejalan dengan pendapat Nur (2014), Kegiatan yang dilakukan berulang-ulang sesi mengemukan pendapat untuk meyelesaikan masalah memberikan kesempatan kepada siswa serta menbantunya terbiasa untuk mengungkapkan ide sebanyak-banyaknya. Fleksibilitas (Flexibility) merupakan indikator berpikir kreatif yang juga mengalami peningkatan signifikan setelah indikator kelancaran (fluency). Fleksibilitas merupakan karakteristik yang mendeskripsikan kemampuan seseorang untuk mengatasi rintangan mental, mengubah pendekatan dari sebuah masalah. Fleksibilitas dari kemampuan siswa terlihat dalam mengungkapkan ide yang berbeda untuk menyelesaikan masalah. Hal ini disebabkan pada saat proses pembelajaran, guru memberikan penekanan kepada siswa bahwa setiap siswa mampu mengungkapkan ide kreatif dalam beberapa bentuk.

Selanjutnya untuk indikator elaborasi (Elaboration) dan keaslian (originality), kedua indikator ini terdapat perbedaan skor yang rendah antara dari hasil pre test dan post test, untuk itu perlu adanya latihan yang berkelanjutan dalam mengembangkan 
perangkat pembelajaran berpikir kreatif, terutama terhadap indikator elaborasi (Elaboration) dan keaslian (originality).Curtis (2003), menyatakan bahwa Elaborasi ditunjukkan dari sejumlah tambahan dan detail yang bisa membuat rangsangan sederhana menjadi lebih kompleks. Keaslian (originality) merupakan indikator yang paling sulit dilatihkan kepada siswa, ini karena siswa terpaku dan terpengaruh oleh beberapa hal yang dijelaskan di buku siswa mengenai cara mengatasi permasalahan dalam materi pencemaran lingkungan. Terlihat masih belum luwes mengemukan ide karena terpaku pada buku siswa pada saat mengatasi permasalahan, padahal seharusnya masih ada ide yang lain selain dari buku siswa.

Pada dasarnya elaborasi merupakan jembatan terhadap siswa dalam mengkomunikasikan ide kreatif dalam lingkungan masyarakat. Hal sependapat dengan Levinger (Filsaime, 2008), jika guru mampu melatihkan keterampilan berpikir tingkat tinggi, maka siswa akanmampu berpikir kritis dan kreatif, kemampuan tersebut sangat diperlukan dalam membangun karakter pribadi yang mandiri serta mampu menggelola proses pembelajaran sendiri (self regulated learning), serta membantu pengetahuannya sendiri sehingga siswa tersebut dapat dikatakan mempunyai kemampuan berpikir tingga tinggi.Namun secara keseluruhan, peningkatan kemampuan berpikir kreatif siwa pada ujicoba penelitian terhadap 35 siswa kelas VII SMPN 2 Kembang Tanjong secara keseluruhan memberikan informasi bahwa tes kemampuan berpikir kreatif siswa pada saat pre-test diperoleh rata-rata45 dengan kategori cukup kreatif dan pada posttest diperoleh rata-rata71 dengan kategori kreatif.

Pemberian pretest dan posttest bertujuan untuk mengetahui sensitivitas setiap butir soal dan skor peningkatan (Ngain-score) yang diperoleh dari setiap siswa. Skor N-gain dinyatakan berkategori tinggi, sebab rata-rata yang diperoleh sebesar 0,78 (Hake, 1999).Hal ini sesuai dengan pendapat
Muslimin (2005), butir soal yang mempunyai nilai sensitivitas $\geq 0.30$ memiliki kepekaan efek-efek pembelajaran. Indeks sensitivitas pada dasarnya merupakan ukuran seberapa baik butir soal tersebut dalam pembelajaran untuk membedakan antara siswa yang telah dan belum mengikuti kegiatan belajar (Ratumanan dan Laurens,2011).

Adanya pembelajaran didesain sedemikian yang memungkinkan siswa dapat membangun pengetahuan sendiri atau menjadikan informasi milikinya sendiri, dan peran guru bertindak sebagai fasilitator. Adanya pemahaman siswa terhadap konsep yang telah dipelajari maka akan meningkatkan hasi belajar siswa. Hasil penelitian ini juga sejalan dengan hasil peneltian yang dilakukan oleh Wulandari, Nugroho dan Putut (2013) tentang penerapan pembelajaran model siklus belajar dapat mengoptimalkan aktivitas dan hasil belajar siswa pada materi jamur di SMA. Lebih lanjut penelitian yang dilakukan oleh Risdiana (2014), mengungkapkan bahwa model learning cycle $5 E$ dapat melatih kemampuan berpikir kreatif siswa dan pemahaman konsep siswa. Peningkatkan sikap ilmiah siswa, daya serap belajar, ketuntasan individu dan aktivitas siswa.Hal ini didukung oleh penelitian Purwanti dalam (Indriyani, 2013) tentang learning cycle sebagai upaya menciptakan pembelajaran bermakna memberi keuntungan untuk meningkatkan motivasi belajar karena siswa terlibat secara aktif dalam proses pembelajaran, membantu mengembangkan sikap ilmiah siswa, dan juga pembelajaran lebih bermakna.

\section{Temuan Penelitian.}

Berdasarkan hasil analisis dan pembahasan hasil penelitian pengembangan perangkat dan penerapan pembelajaran Learning cycle 5Euntuk melatih kemampuan berpikir kreatif di SMP, ditemukan beberapa hal sebagai berikut:

1. Perangkat pembelajaranLearning cycle 5 Euntuk melatih kemampuan berpikir kreatif di SMP materi Pencemaran 
lingkungan yang telah dikembangkan dinyatakan valid dan dapat digunakan dalam kegiatan pembelajaran yang diterapkan diSMP.

2. Kepraktisan perangkat IPA dikembangkan yang sudah diimplementasi adalah:

a. Hasil pengamatan dari keterlakasanaan RPP 1, RPP 2, dan RPP 3 dalam proses pembelajaran masuk dalam pada kategori sangatbaikdengan persentase $100 \%$

b. Hasil aktivitas siswa yang lebih dominan selama tiga kali pertemuan dalam proses pembelajaran seperti terlibat aktif, mengalisa data, diskusi kelompok, serta mengumpulkan data. Berdasarkan hasil data sehingga dapat disimpulkan perangkat pembelajaran yang telah dikembangkan memiliki kategori praktis dalam meningkatkan kemampuan berpikir kreatif siswa.

c. Respon siswa dari kegiatan proses pembelajaran dari hasil pengembangan perangkat pembelajaran adalah sangat positif. Hal ini menggambarkan bahwa model Learning cycle $5 E$ dapat meningkat kemampuan berpikir kreatif siswa.

3. Keefektifan perangkat pembelajaran IPA melalui implementasi uji coba 2 dengan model Learning cycle 5 Edapat melatih kemampuan berpikir kreatif, hal terlihat dari instrument tes yang digunakan memiliki tingkat $\mathrm{N}$-gain berkategori tinggi sebesar 0,78 .

\section{SIMPULAN DAN SARAN}

\section{A. Simpulan}

Berdasarkan hasil penelitian yang telah dilakukan, maka dapat disimpulkan bahwa perangkat.Perangkat Pembelajaran IPA Model Learning Cycle 5E pada materi Pencemaran Lingkungan dinyatakan layak dan dapat meningkatkan kemampuan berpikir kreatif siswa SMP kelas VII

\section{B. Saran}

Beberapa saran dapat dikemukakan oleh peneliti berdasarkan penelititan yang telah dilakukan adalah sebagai berikut:

1. Penerapan rencana pelaksanaan pembelajaran sudah baik namun guru harus lebih dapat mengelola waktu selama pembelajaran agar pembelajaran bisa berjalan lebih efektif dan efisien

2. Pengembangan perangkat pembelajaran model Learning cycle $5 E$ dapat melatihkan kemapuan berpikir kreatif sehingga perlu dikembangkan secara lebih luas pada materi IPA lainnya.

3. Pada pelaksanaan pembelajaran peran guru sebagai fasilitor dan motivator sehingga dapat meningkatkan motivasi belajar secara aktif secara optimal.

4. Perlu adanya persiapan dan penggelolaan waktu yang baik dalam menerapkan model Learning cycle 5E, sehingga pembelajaran berjalan efektif dan efisien. Hal ini perlu diperhatikan dikarena siswa mendapat banyak kesempatan untuk melatih kemampuan berpikir kreatif.

5. Indikator yang paling sulit dilatih berpikir kreatif yaitu keaslian dan elaborasi. Keaslian menjadi indikator yang paling sulit dilatihkan kepada siswa, dikarena siswa masih terpengaruh dan berpedoman pada buku dalam menyelesaikan/mengatasi permasalahan materi pencemaran lingkungan. Perlu adanya penelitian lanjutan dalammenekankan siswapada pentingnya pemahaman konsep serta keluasan wawasan supaya saat memberi ide, mereka dapat memberi penjelasan pada masing-masing idenya secara optimal.

\section{DAFTAR PUSTAKA}

Arifin, S. (2010). Evaluasi Pembelajaran Prinsip, Teknik, dan Prosedur. Bandung: Remaja Rosdakarya. 
Anwar, H., Jamaluddin.,dan Jufri,A.W. (2016). Pengembangan Perangkat Pembelajaran IPA Model 5E di SMP.

Aydin, N., and Yilman, A. (2010). The Effect of Contructivist Approach in Chemistry Education on Students' Higher Order Cognitive Skill. H.U. Journal of Education, Vol 39, pp 5768.

Bybee, R. W. (2009). The BSCS 5E Instructional Model and $21^{S T}$ Century Skills. A Commissioned Paper Prepared For a Workshop on Exploring The Intersection of Science Education and The Development of $21^{\text {ST }}$ Century Skills.

Campbell, N.A., Reece, J.B., Urry, L.A., Cain, M.L., Wasserman, S.A., Minorsky, P.B., and Jackson, R.B. (2010). Biology (Eight edition). San Fransisco: Pearson Education.

Filasaime, D.K. (2008). Menguak Rahasia Berpikir Kritis dan Kreatif. Jakarta: Prestasi Pustakaraya.

Hake. (1999). Analyzing change/gain scores. (Online). Tersedia http://www. physicsindiana.edu/sdi/AnalyzingChange-Gain. pdf.

Hardiyasa,I.M.,Suma.K.,Sadia,I.W. (2014). Pengaruh Model Siklus Belajar 5E Terhadap Keterampilan Berpikir Kreatif dan Motivasi Berprestasi Siswa.e-jurnal Program Pascasarjana Universitas Pendidikan Ganesha Program Studi IPA. Vol 4. Tahun 2014.

Ibrahim, M. (2010). Assessmen Berkelanjutan, Konsep Dasar Tahapan Pengembangan dan Contoh. Surabaya: Unesa University Prees.
Ibrahim M. (2005). Asesmen Berkelanjutan: Konsep Dasar, Tahapan Pengembangan dan Contoh. Surabaya: Unesa Unirvesity Press.

Mulyasa, E. (2014). Pengembangan dan Implementasi Kurikulum 2013. Bandung: PT. Remaja Rosdakarya.

Munandar, U. (2009). Pengembangan Kreatifitas Anak Berbakat. Jakarta: Rineka Cipta.

Nasih, M., Jufri,W., dan Muklis. (2015). Pengembangan Perangkat Pembelajaran Model 5E untuk Meningkatkan Kemampuan Berpikir Kristis Siswa. e-Jurnal Penelitian Pendidikan IPA. Vol.1. No.2 Tahun 2014.

Nur, M. (2011). Modul Keterampilanketerampilan Proses dan Hakikat Sains. Surabaya: PSMS Unesa.

Nur, M. (2014). Berpikir KreatifSurabaya: Penelitian Unggulan Perguruan Tinggi UNESA.

Piitro, J. (2011). "Creativity for 21" Century Skills. Rotterdam: Sense Publishers.

Putra, S.R. (2013). Desain Belajar Mengajar Kreatif Berbasis Sains. Yogyakarta: Diva Press.

Sayuti,I., Rosmaini, S., Andayani. (2012). Penerapan Model Pembelajaran model Learning cycle 5e untuk Meningkatkan Sikap Ilmiah dan Hasil Belajar Siswa Biologi kelas XI IPA4 SMA Negeri 5 Pekan Baru. JurnalPendidikanUnri, Vol. 3. No.1.

Suprihatiningrum, J. (2014). Strategi Pembelajaran Teori dan Aplikasi. Jogjakarta: Ar-Ruzz Media.

Slavin, Robert E. (2011). Psikologi Pendidikan Teori dan Praktik Edisi 
Kesembilan Jilid 1: Teori dan Praktik.Jakarta: PT Indeks.

Thomsom, S., Lisa, D.B., Sarah,B. (2014). PISA in Brief: Highlights from The Full Australian Report. ACER: Australian Council of Educational Research.

Undang-undang Nomor 32 Tahun 2009 tentang Perlindungan dan Penggelolaan Lingkungan Hidup.

Ratiyani,I.,Subchan,W.,Hariyadi Slamet. (2012). Pengembangan Bahan Ajar Digital dan Aplikasi dalam Model Siklus Pembelajaran 5E (Learning Cycle 5E) Terhadap Aktivitas dan Hasil Belajar (Siswa Kelas VII di SMP Negeri 10 Probolingo Tahun Ajaran 2012/2013). Jurnal Pancaran Universitas Jember. Vol.3,No.1,pp 79-88. Februari 2014.
Riduwan. (2010). Skala Pengukuran Variabel-variabel Penelitian. Bandung: Alfabeta.

Risdiana, H., Suyatno, Sri, P. (2014). Implementasi Model 5E Learning cycle untuk meningkatkan Penguasaan konsep dan Kemapuan Berpikir Siswa SMA. Jurnal Penelitian Sains, Vol. 2., No.3, pp 174-183.

Zuraida.(2017).Pengembangan Perangkat Pembelajaran Biologi Model Siklus Belajar 5E Untuk Meningkatkan Hasil Belajar Siswa SMA pada Materi Ekologi. Prosiding Seminar Nasional Biologi 2017. Universitas Syiah Kuala Jurusan Pendidikan Biologi. 